\title{
THE MAKING OF RUSSIAN FEMALE SOCIAL DEMOCRATS, 1890-1917*
}

SUMMARY: The social composition of female RSDRP members (who constituted between $11 \%$ and $15 \%$ of the total party membership) prior to 1917 is analyzed using prosopographic methods. The analysis reveals that women social democrats tended to come from higher social classes, and to have a higher educational attainment, and professional occupations. Thus, it is misleading to characterize the RSDRP as a "workers' party", for only its male contingent was composed mostly of workers.

The analysis of the process of radicalization reveals the cultural barriers which these women had to overcome before they would join the party. Breaking free from their role in society meant, for them, leading fuller lives as women and an opportunity to dedicate themselves to the people.

The primary purpose of this article is to examine the collective traits of Russian female social democrats in order to identify the social characteristics of these revolutionaries, to gain insight into the cultural milieu in which they grew up, and to determine the factors which facilitated their turn to radicalism. The use of prosopographic and collective biographical methods seemed most appropriate for such a survey.

\section{Sources}

Contemporary sources concerning the size, composition and membership of the Rossiiskaia Sotsial-Demokraticheskaia Rabochaia Partiia (RSDRP) in pre-1917 Russia are rare, for the party organizations avoided keeping membership records. What might have been a proper strategy to protect social-democratic activists in the past from police persecution, today works against the historians of the party and imposes serious handicaps. It is particularly difficult to find data on the female contingent of the RSDRP; conventionally, pre-revolutionary sources remain silent about women members.

Although there is a considerable literature on social democracy in prerevolutionary Russia, scholarship has given little attention to the history of women in the RSDRP. So far, neither social histories of the RSDRP nor

* This article is a revised and substantially extended version of a paper given at the conference "Women in the history of the Russian Empire", University of Akron and Kent State University, U.S.A., August 1988. 
prosopographic analyses, which have provided useful data on the party as a whole, have provided analyses in terms of gender. ${ }^{1}$

The following analysis has relied mainly on Deiateli Revoliutsionnogo Dvizheniia v Rossii. Bio-Bibliograficheskii Slovar ${ }^{2}$ which includes concise biographies of all women and men identified as social democrats prior to 1905. Unfortunately, it covers only the surnames beginning with A, B, V, and G-Gm. ${ }^{3}$ However incomplete, this volume is the most reliable biographical dictionary of social democrats available, as it is based on archival material, police files, party records, party histories, as well as on autobiographical sketches of the activists themselves. Since most of the entries were compiled in the 1920 s, there is good reason to trust the information which is presented.

My second major source was the membership list of the All-Union Society of Former Political Convicts and Exiles, three editions of which were published in 1927,1930 , and 1934 , respectively. ${ }^{4}$ A principal disad-

${ }^{1}$ David Lane, The Roots of Russian Communism. A Social and Historical Study of Russian Social Democracy 1898-1907 (Assen, 1975); W.E. Mosse, "Makers of the Soviet Union", Slavic and East European Review, 46 (1968), pp. 141-154; William Chase and J. Arch Getty, "The Moscow Bolshevik Cadres of 1917: A Prosopographic Analysis", Russian History, 5 (1978), pp. 84-105.

${ }^{2}$ V. Vilenskii-Sibiriakov et al. (eds), Deiateli Revoliutsionnogo Dvizheniia v Rossii. Bio-Bibliograficheskii Slovar. Ot Predshestvennikov Dekabristov do Padeniia Tsarizma, five volumes (Moscow, 1927-1933), Vol. V: E.A. Korolchuk and Sh.M. Levin (eds), Sotsial-Demokraty 1880-1904, Vypusk I, A-B, Vypusk II, V-Gm.

Lane's study (see footnote 1 ) has also relied on this biographical dictionary as a major source.

${ }^{3}$ After the publication of these first two installments in 1931-1933, the project was discontinued. However, manuscripts concerning the letters $\mathrm{Gm}-\mathrm{Kar}$ (in 19 volumes along with 52 volumes of autobiographical sketches) do still exist in Soviet archives and Soviet historians are currently working with this material. They will probably revive this big undertaking with the support of the computer facilities now available. See, for example: V.V. Lozhkin, "K Voprosu ob Izuchenii Sostava Uchastnikov Sotsial-Demokraticheskogo Dvizheniia v Rossii (1883-1903gg.) (Metodika Obrabotki Dannykh)", Istoriia SSSR, 2 (1983), pp. 89-95; Feliks Tych, "Lexikalische Hilfsmittel zur Geschichte der Arbeiterbewegung”, Internationale Wissenschaftliche Korrespondenz zur Geschichte der Arbeiterbewegung, 19 (1983), p. 160.

${ }^{4}$ Uchastniki Russkogo Revoliutsionnogo Dvizheniia Epochi Borby s Tsarizmom. Biograficheskii Ukazatel Chlenov Vsesoiuznogo Obshchestva Politicheskikh Katorzhan $i$ Ssylno-Poselentsev (Moscow, 1927); Politicheskaia Katorga i Ssylka, Biograficheskii Spravochnik Chlenov Obshchestva Politkatorzhan i Ssylno-Poselentsev, 2nd edition (Moscow, 1930); 3rd edition (Moscow, 1934). Material for the Tables presented in this paper was taken from the 2 nd edition (1930), for the 3 rd edition (1934), which is considered to be the most complete, was not available. Amy Knight has based her comparative analysis of both social-democratic as well as socialist-revolutionary women and men on the 3rd edition. Whenever that edition is referred to in this article, the data are taken from: Amy W. Knight, "The Participation of Women in the Revolutionary Movement in Russia from 1890 to 1914" (Ph.D., London School of Economics, 1977). Maureen Perrie and Manfred Hildermeier also worked with the 1934 edition (see below). 
vantage, in addition to its relatively incidental nature is that the compilers of Politicheskaia Katorga i Ssylka. Biograficheskii Spravochnik Chlenov Obshchestva Politkatorzhan i Ssylno-Poselentsev organized the entries according to the testimony of the society's voluntary members alone. Thus, one may suspect biases, for example in presentation of social origin, which in the 1930s became a very sensitive issue. Yet, in welcome contrast to the other volume mentioned, this biographical dictionary not only covers all letters of the Russian alphabet, but also treats the whole period from the 1880 s up to 1917 . When used together, these two sets of sources therefore represent a sound basis on which to identify trends in the social composition of the female party membership of the RSDRP in pre-1917 Russia.

Size

Although estimates of the actual size of RSDRP membership in prerevolutionary Russia do not offer any breakdowns by sex,${ }^{5}$ it is possible to calculate the approximate number of women social democrats on the basis of entries in Deiateli, though not using material enclosed in Politicheskaia Katorga i Ssylka. The total number of female party members listed in Deiateli whose surnames begin with the letters A or B is 210 . According to the method developed by Lane, about $10 \%$ of all Russian names begin with these first two letters of the alphabet $;{ }^{6}$ hence, one may estimate that some 2100 women were actively involved in the Russian social-democratic movement prior to 1905 ; male party members, on the other hand, made up a total of about 12,320. Altogether, Deiateli provides information on 374 women social democrats, and they account for about $15 \%$ of all entries in the book. In comparison, only $11 \%(\mathrm{~N}=107)$ of those referred to in the 1930 edition of Politicheskaia Katorga i Ssylka are female party members; in the 1934 edition, women make up $11.5 \%$ of the total $(\mathrm{N}=125) .{ }^{7}$ We may conclude from this evidence that women represented a significant minority, around $15 \%$ within the RSDRP members prior to 1905 , while their proportion declined on average after the first Russian revolution. It appears that official data on the proportion of female party members in 1917 do not exist, ${ }^{8}$ and the first party census was not taken until 1922; according to a contemporary report, women represented only $7.8 \%$ of all party members

\footnotetext{
${ }^{5}$ Lane, Roots of Russian Communism, pp. 12-13.

${ }^{6}$ Ibid., p. 14.

7 Knight, "Participation of Women", p. 195.

${ }^{8}$ Marcelline J. Hutton, "Russian and Soviet Women, 1897-1939: Dreams, Struggles, and Nightmares" (Ph.D., The University of Iowa, 1986), p. 171, gives a figure which suggests that $2 \%$ of the RSDRP membership in 1917 were women, but she does not specify her source.
} 
by that year. ${ }^{9}$ This downward trend does not imply a decline in absolute numbers as well; one may suspect that it was rather due to a massive influx of male party members ${ }^{10}$ while women did not enter the RSDRP in such large numbers as before.

In order to evaluate the scope of female participation in the RSDRP, it should be compared with the proportions of women active in other revolutionary or feminist organizations of the time. The female radical contingent in the 1860 s had not made up more than $3 \%$ of the total, ${ }^{11}$ but in the following decades the proportion of women among revolutionaries and terrorists had risen to 12 to $15 \% .{ }^{12}$ On average, $15 \%$ of the members of the Socialist Revolutionary Party (PSR), which competed with the RSDRP prior to 1917 , were women. ${ }^{13}$ These figures suggest that female participation in the Russian revolutionary movement remained remarkably constant well into the twentieth century, once it had gained momentum in the 1870s; in numerical terms it grew dramatically. It is true that the PSR could boast of a slightly higher percentage of female members than the social democrats; but nevertheless, social-democratic women outnumbered their socialist-revolutionary rivals by far. ${ }^{14}$

The RSDRP in fact had the largest percentage of women members of all European socialist parties of the time, whose female contingent usually amounted to 5 to $10 \% .{ }^{15}$ In contrast to this, feminist organizations in all Western European countries surpassed the Russian branch in size. Russian feminism expanded quickly and dynamically, and reached a peak in 190506 , but it declined sharply soon after. ${ }^{16}$ Thus it lacked the constancy and continuity which proved to be typical of female participation in the Russian revolutionary movement. It was a Russian peculiarity that radical women preferred embracing the 'common cause' to creating a socialist women's movement - an attitude which might be partly explained by the political situation prevailing in Imperial Russia: as long as both sexes were denied political rights, social-democratic women may still have found it as natural

9 E. Smitten, "Zhenshchiny v RKP”, Kommunistka, 1-2 (1923), p. 30.

${ }^{10}$ Lane, Roots of Russian Communism, pp. 12-15.

${ }^{11}$ Richard Stites, The Women's Liberation Movement in Russia. Feminism, Nihilism, and Bolshevism, 1860-1930 (Princeton, 1978), p. 148.

12 Ibid., pp. 148-149; Andreas Kappeler, "Zur Charakteristik russischer Terroristen (1878-1887)", Jahrbücher für Geschichte Osteuropas, 27 (1979), pp. 524-525.

${ }_{13}$ Maureen Perrie, "The Social Composition and Structure of the Socialist-Revolutionary Party Before 1917", Soviet Studies, 24 (1972), p. 235.

${ }_{14}$ Manfred Hildermeier, Die Sozialrevolutionäre Partei Rußlands. Agrarsozialismus und Modernisierung im Zarenreich (1900-1914) (Cologne, 1978), p. 269.

${ }^{15}$ Heinz Niggemann, Emanzipation zwischen Sozialismus und Feminismus. Die sozialdemokratische Frauenbewegung im Kaiserreich (Wuppertal, 1981), p. 78; Smitten, "Zhenshchiny v RKP", p. 30; Hutton, "Russian and Soviet Women", pp. 44 and 101.

${ }^{16}$ Stites, Women's Liberation Movement, p. 227. 
and as appropriate as their narodnik predecessors to fight shoulder to shoulder with men, who - at least theoretically - were not opposed to the idea of equality of the sexes.

\section{Activity and hierarchy}

Table 1 shows various degrees of activism of the female and the male membership of the RSDRP, as well as their representation at different organizational levels. It appears that the pre-1905 sample of female members tended to be more active than their male counterparts (see columns A and B), since the percentage of women who were local leaders was almost twice that of men. Compared with their numbers in the RSDRP, women comprised a similar proportion of the rank-and-file and of the activist groups (column C), but they were clearly overrepresented among the local leaders. Columns D and E of Table 1 suggest that in pre-1917 Russia female and male party-members had become considerably less active on average, though this trend was especially marked among women. Probably the so-called "years of reaction" (1908-1912) contributed to this slowing-down in activism. Memoirs indicate that while exiled to Siberia, former female activists often dropped out of RSDRP service in favour of family life, and returned to party work only after the February revolution. In the pre-1917 group, women social democrats were still slightly overrepresented among the local leaders when compared with their numerical strength in the party (column F), but no longer as significantly as prior to $1905 .{ }^{17}$ Perhaps the best-known example of this type of female local leader was Elena Stasova, long-time secretary of the St. Petersburg committee of the RSDRP. 'Comrade Absolute' was both admired and dreaded by younger party activists because of her legendary precision and strictness.

As a result, it emerges from Table 1 that social-democratic women displayed a high degree of activism in the pre-1905 period, but became considerably more passive later, when the political situation had changed for the worse. Before 1905, they had an overproportionate and after the first revolution still fair chance to rise to the level of local leader; though the evidence is scarce, it does seem to suggest that female party members could only seldomly overcome the barriers which prevented them from achieving top leadership positions in the RSDRP however.

${ }^{17}$ In comparison, socialist revolutionary women were even more overrepresented among the local party leaders (24\%); see Knight, "Participation of Women", p. 195; Perrie, however, does not acknowledge a significant difference in the participation of women at different organizational levels (Perrie, "Social Composition and Structure", p. 235), though her finding may stem from a divergent definition of "local leader". 


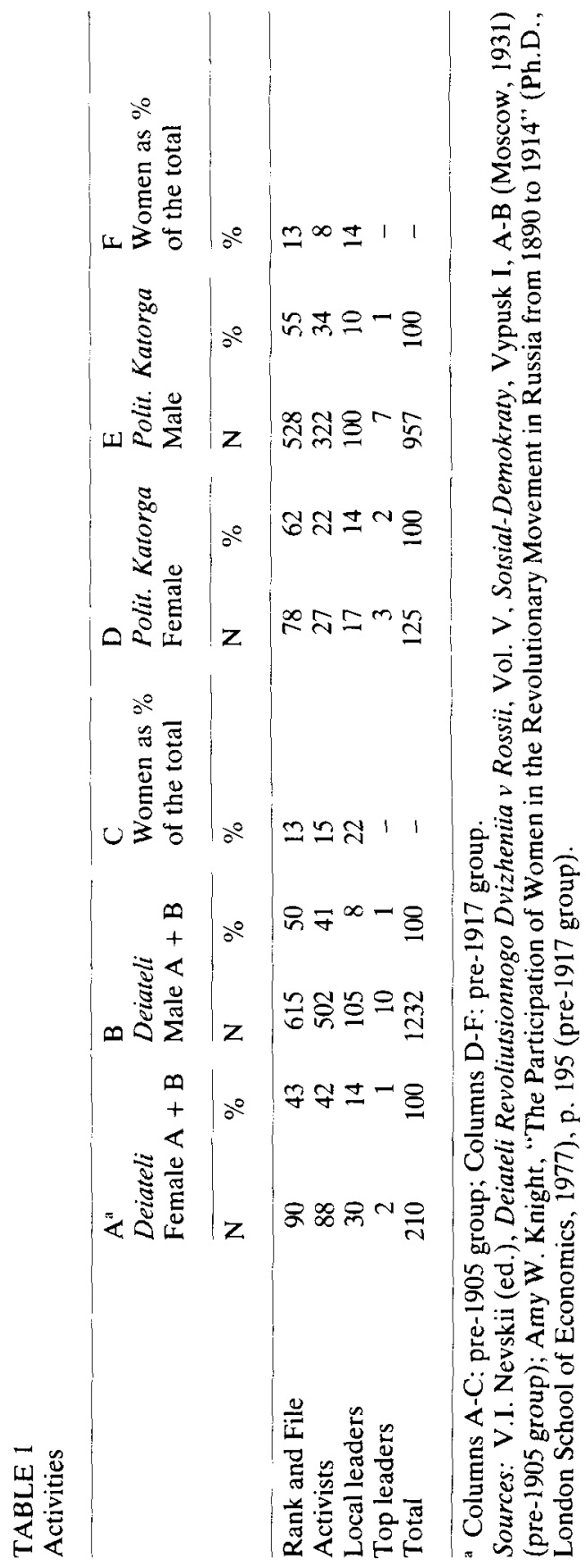




\section{Age and revolutionary experience}

It is apparent from Table 2 that the age distribution and average age of female party members closely resembled those of their male counterpart in the pre-1905 sample (columns A and B). In 1904, men had an approximate average age of 28 years, and women 27 years. Women local leaders were substantially older than the female group as a whole; their average age in 1904 was 32.3 years (column C). Accordingly, it would be misleading to describe Russian social democracy prior to 1905 as a party of youth - it rather represented a movement of mature adults. Only after the first Russian revolution had brought a substantial influx of teenagers did the RSDRP become increasingly younger, so that the average age of female social democrats had fallen to almost 23 years by 1906 (column D).

In contrast to those who joined prior to 1905 , who had been radicalized gradually during a long time of searching for a cause to adopt, the "generation of 1905" underwent quick and sudden politicization, and therefore committed itself to social democracy without having taken the detours that their older colleagues had, and they therefore joined at an earlier age, many of them were still at school. After 1905 the social-democratic movement shared the generally youthful quality of other European revolutionary movements, and became more similar to contemporary radical groups inside Russia. ${ }^{18}$ In the pre-1917 sample compiled by Knight, ${ }^{19}$ the age difference between female RSDRP members and local leaders was only one year, compared with seven years in the group of socialist revolutionary women. ${ }^{20}$ Seniority obviously counted more in the PSR than in the RSDRP, a party in which women of only 25 years of age could already fill leadership positions.

Table 3 allows us to distinguish at least two "waves" of social-democratic women who had been radicalized, each under similar conditions. There were those who joined the RSDRP prior to 1905 (including those who had been affiliated to the social-democratic movement before the party was founded in 1898), and those who made their political debut during the first Russian revolution (columns A and D). In the pre-1917 sample the female social democrats were rather equally divided between these two groups, which attests to their high level of continuity (column D). The former group grew up during the revolutionary 1870 s or the "preparatory" 1880 s, and probably developed their first radical inclinations while volunteering to

${ }^{18}$ Kappeler, "Charakteristik russischer Terroristen”, p. 527; Hildermeier, Sozialrevolutionäre Partei Rußlands, p. 291; Perrie, "Social Composition and Structure", p. 230.

19 Knight, "Participation of Women", p. 196.

${ }^{20}$ Ibid. 


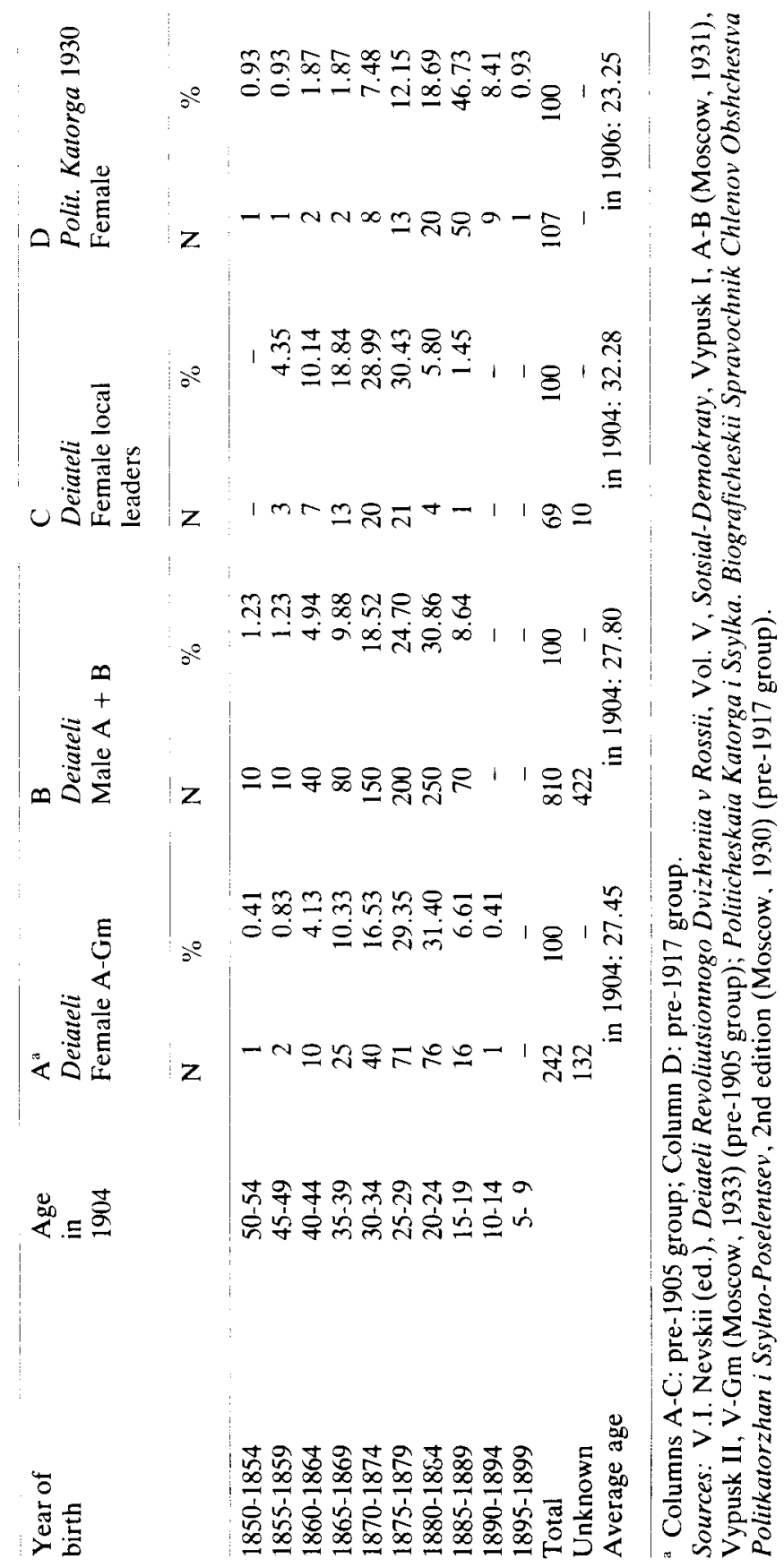




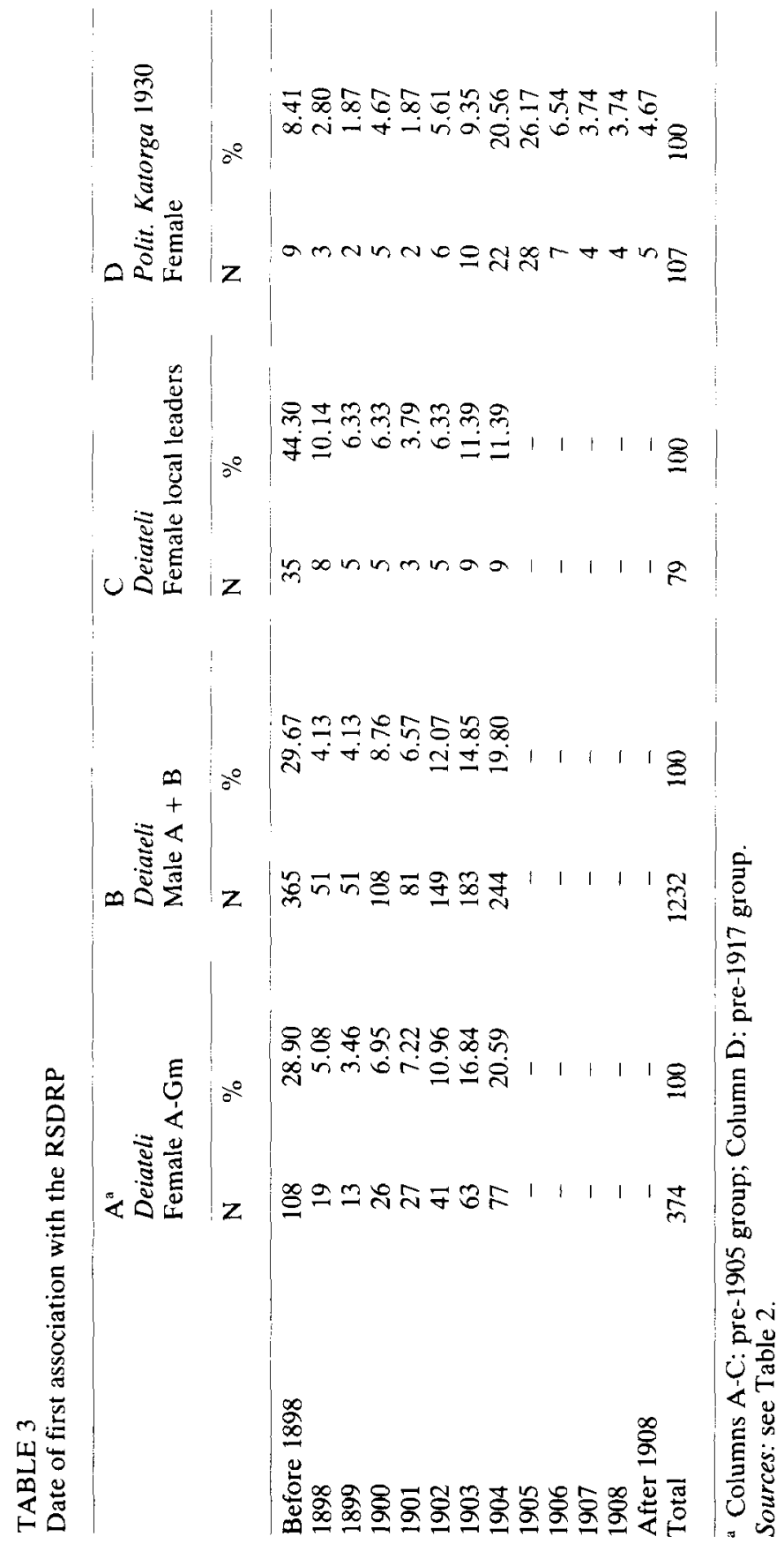


fight famine in 1891-92. The next generation would be quickly swept up by the maelstrom of revolutionary turmoil around 1905.

While the local leaders in the pre-1905 sample were overproportionately drawn from the "old social democratic women" with pre-1898 experience (column C), Knight's evidence suggests that in the pre-1917 group they were recruited more and more from among the "generation of 1905 ", ${ }^{21}$ and were, concomitantly, less experienced in politics. In the PSR, however, age, in combination with the length of party service, was still a major precondition in attaining positions of responsibility. ${ }^{22}$

An analysis of the social composition of female RSDRP members can tell us more about who they were. The social status of a person in society is determined by social origin, education, and occupation; information concerning these characteristics is set forth in the following tables.

\section{Social origin}

The entries in Deiateli usually do not refer to parental occupations but to "estate" as an indicator of social origin instead. In Imperial Russia, the population was registered according to the legal categories of "estate" (soslovie) as "nobility", "merchants", "meshchane" (townspeople), "raznochintsy" (people of diverse ranks), "clergy" or "peasants". Yet "estate" was neither equivalent to the present occupation nor to the economic situation of the person referred to, and therefore was not identical to "class".

As is evident from Table 4, both female and male party members were drawn disproportionately from the higher estates (columns A and B). More than half of all women and men actively involved in Russian social democracy prior to 1905 came from the meshchanstvo, which attests to the urban roots of, and support for, the party. Only $10.7 \%$ of the total population of Imperial Russia, but $44.3 \%$ of its urban population were listed as meshchane. ${ }^{23}$ Even if both sexes were similar in having a preponderantly middleclass background, the most noticeable difference between the female and male party members was the remarkably high proportion of women originating from the nobility and the merchant estates: $23 \%$ compared with $9 \%$ of men. Male party members, on the other hand, were recruited to a considerable degree from the peasant estate $(24 \%)$, whereas women of peasant stock accounted for only $9 \%$ of all female members in the RSDRP. These were migrant peasants, that is workers by occupation, of course.

${ }^{21}$ Ibid.

${ }^{22}$ Hildermeier, Sozialrevolutionäre Partei Rußlands, p. 291; Perrie, "Social Composition and Structure", pp. 234-235.

${ }^{23}$ Lane, Roots of Russian Communism, p. 21; A.G. Rashin, Naselenie Rossii za 100 Let (1811-1913). Statisticheskie Ocherki (Moscow, 1956), p. 123. 


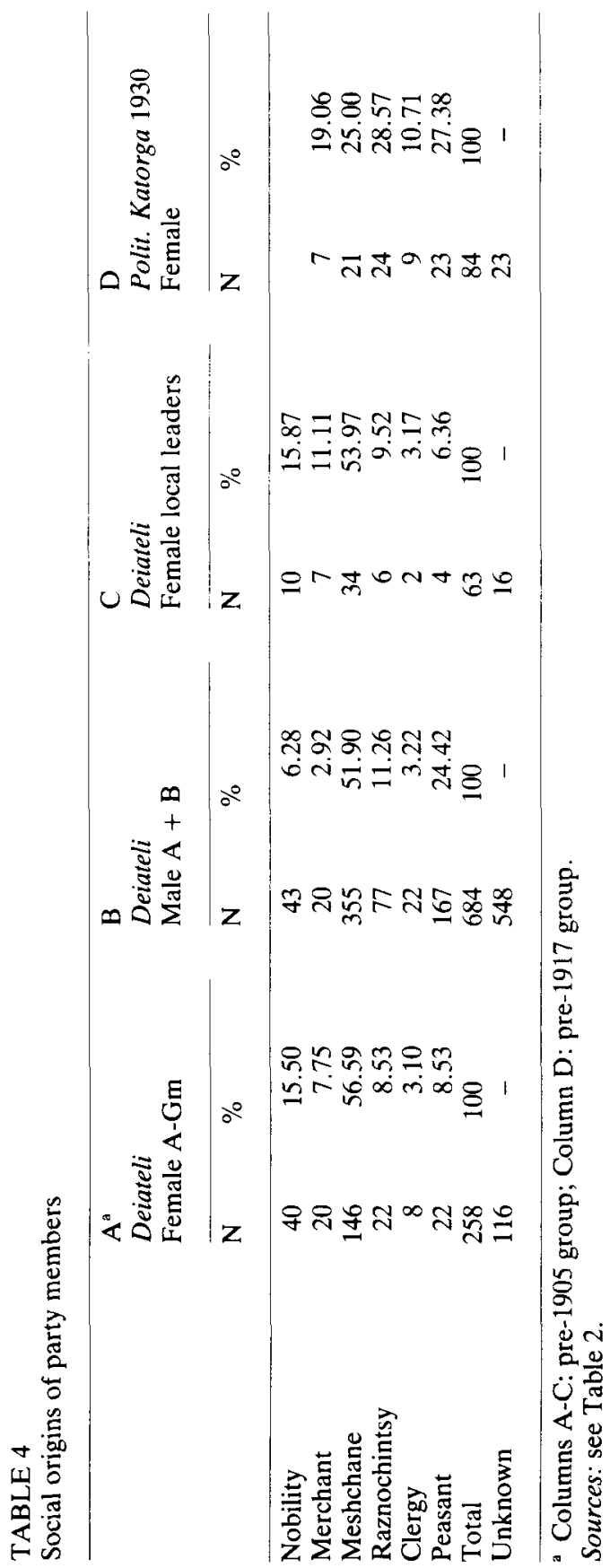


Thus, the Russian social-democratic party prior to 1905 can be described as a meshchanstvo party, with a strong minority of female members coming from the upper estates, while its male membership displayed a pronounced trend towards origins in lower estates. On the whole, male party members rather than women social democrats reflected the social composition of the urban population of the Russian Empire. ${ }^{24}$ A separate analysis of pre-1905 female local leaders (column $\mathrm{C}$ ) did not reveal any marked differences. They were drawn rather proportionally from all estates compared with the whole female group - another confirmation of the high degree of inner party mobility prevailing in the RSDRP.

It is somewhat difficult to compare the entries in Deiateli with those in Politicheskaia Katorga i Ssylka, since divergent classifications were used with respect to social origin: Deiateli usually referred to the legal estate, whereas the editors of the latter regarded parental occupation as a more precise indicator. ${ }^{25}$ Our evidence suggests that prior to 1917 women social democrats were still largely characterized by having urban upper-class backgrounds, even if those females of peasant origin now constituted a quarter of the total (column D). Knight's table on pre-1917 social democrats confirms this growing tendency towards lower social origins among both sexes. ${ }^{26}$ Nevertheless, the differences in social composition between female and male party members stand out as clear as before. The female membership of the PSR was not dissimilar in social composition to that of the RSDRP, though it contained on average a slightly higher proportion of those from higher social classes. ${ }^{27}$

Well into the twentieth century, it was mostly Russian women of privileged social backgrounds who were likely to join the revolutionary movement. Having examined the social composition of female radicals of the 1870 s and 1880 s, it became evident that the overall picture had not substantially changed, despite a trend to lower social origins which had manifested itself after $1905 .{ }^{28}$ Contrary to its labeling as a "workers' party", the RSDRP was strikingly unsuccessful in attracting women from the lower social strata as party members. Joining a revolutionary party for a woman implied a sharp break with tradition. It amounted to an escape from her defined social role in society and the family. This radical act of emancipa-

${ }^{24}$ The urban population in Imperial Russia in 1897 was composed of: $6.2 \%$ nobility, $44.3 \%$ meshchane, $38.8 \%$ peasants and smaller groups from other estates; Rashin, Naselenie Rossii za 100 Let, p. 123.

${ }_{25}$ Politicheskaia Katorga i Ssylka, 2nd edition (1930), p. 7.

${ }^{26}$ Knight, "Participation of Women", p. 197.

27 Ibid.

${ }^{28}$ Kappeler, "Charakteristik russischer Terroristen", p. 535; Robert McNeal, "Women in the Russian Radical Movement", Journal of Social History, 2 (1971-1972), pp. 150-151. 
tion could more easily be carried out by such women whose attachment to traditional values had been weakened anyway. In late nineteenth century Russia, only the urban upper-classes provided an environment that was suited to facilitate change; economic necessity often contributed to a broadening of accepted female roles, and to an undermining of customary concepts. Women of peasant origin, whether married to a worker or earning a living as workers themselves, usually retained strong bonds with the countryside and tended to act according to the patriarchal traditions of the village community. To them, the policy of the RSDRP had only meager appeal. Moreover, they might have lacked the basic literacy required to understand the party's leaflets.

\section{Education}

For the purposes of comparative analysis, we have grouped in Table 5 information on education according to four levels: higher, secondary, primary (including "home" and "self-taught") and no education.

It is not very surprising that the higher social backgrounds of female social democrats were also reflected in their educational level. As is evident from Table 5, the majority of women active in the RSDRP prior to 1905 had a higher education $(67.5 \%)$ in contrast with only $46.7 \%$ of male social democrats with university training (columns A and B). Less than $20 \%$ of the women under consideration had only a primary education and virtually none was illiterate, in comparison with $28 \%$ of male party members with a primary and another $8 \%$ who were lacking even an elementary education. On the whole, the educational pattern of both female as well as male social democrats differed significantly from that of the Russian population. In 1897 , for example, not more than $48 \%$ of the female and $66 \%$ of the male, urban population aged between 9 and 49 were literate at all. ${ }^{29}$

As is to be expected, female party members with high educational accomplishment figured prominently as local leaders, since this position required articulate propagandists who could compose leaflets or edit party newspapers. Column $\mathrm{C}$ shows that $82 \%$ of female local leaders had a higher education.

What emerges as the main difference between the pre-1905 group and the pre-1917 sample of female social democrats is that their average level of education had declined (column D). The proportion of women with a higher education had sunk to $21 \%$, while the proportion of those with only a secondary or primary education had more than doubled. As is evident from Knight's analysis, this was a general trend to be observed among RSDRP members. But the characteristic feature of Russian social democracy, that

${ }^{29}$ Norton Dodge, Women in the Soviet Economy (Baltimore, 1966), p. 141. 


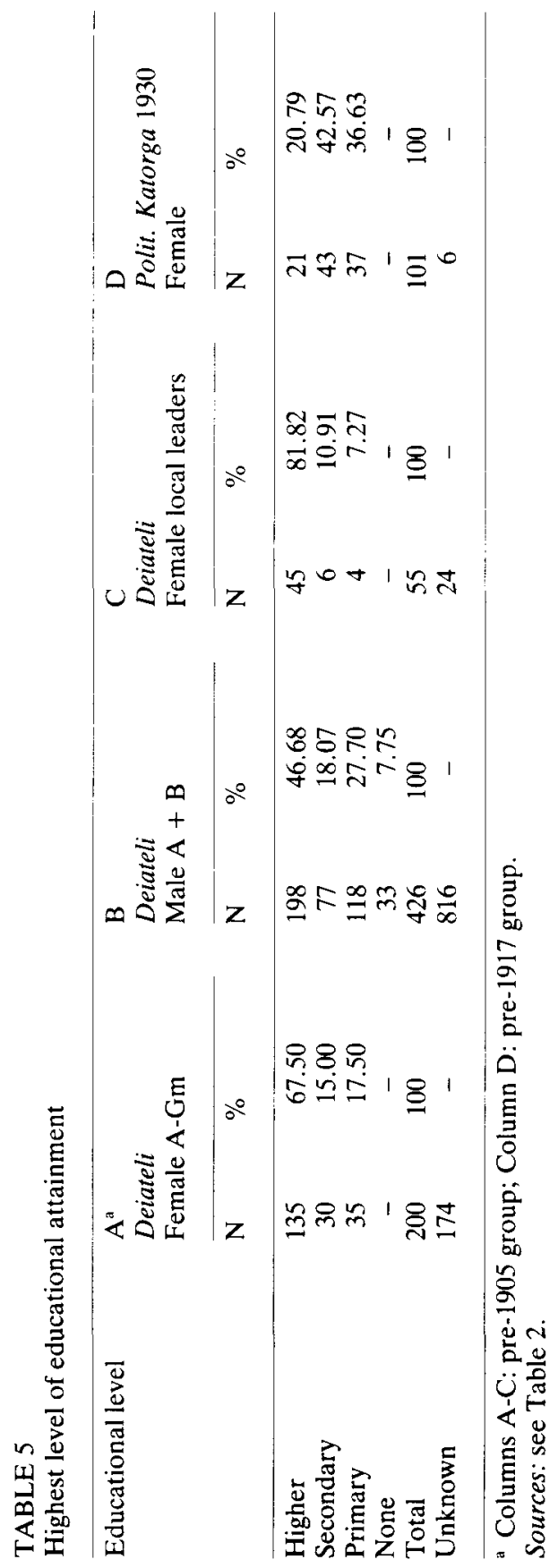


female members tended to be far better educated than males, remained however. ${ }^{30}$ According to Knight's figures more than $70 \%$ of the men listed in her pre-1917 group had acquired only a basic education; the majority of women social democrats had obtained a secondary education in addition. ${ }^{31}$

Members of the PSR, in comparison with the RSDRP, enjoyed a higher educational attainment on average, but displayed the same gender differences in these levels of attainment. ${ }^{32}$

By the low standards of late Imperial Russian society, women social democrats were highly educated and they were largely drawn from the very thin layer of a female élite. This was perhaps their most peculiar attribute, and it was an element which distinguished them sharply from their male counterparts. Yet the educational level of female and male RSDRP members stood in almost reversed relation to the educational opportunities available to women and men in the Russian Empire, where, up to 1917, the ratio of school attendances of girls to boys remained $1: 3 .{ }^{33}$ Only after the first Russian revolution did opportunities for women to obtain a higher education expand substantially, and the numbers of "kursistki" rapidly increased.$^{34}$ It is all the more surprising then that the proportion of better educated female social democrats began to decline exactly from that time onwards. An interpretation of this opposite trend must certainly take into account the political depression and the disappointment of the student body, which contributed to a cooling of radicalism during the "years of reaction". Moreover, the second and third generations of female students, who were no longer pioneers in the field of sacred knowledge, had certainly developed a keen sense of professional training and career orientation in the meantime. Indeed, more and more employment opportunities for women opened up in the liberal professions and in the civil service by this time. ${ }^{35}$ In contrast to them, the first generation of kursistki with a social democratic outlook tended to be less determined with regard to professional accomplishments. Women who enrolled in the Higher Courses during the 1890 s compared this step to committing a revolutionary, or at least decisive, emancipatory act. Quite a few memoirs support the impression that they were driven by a deeply-felt obligation to "serve the people", to discover universal truth. Given this preconditioning, the courses served them better as a training ground for political radicalism than for professional preparation. It was true for most social democratic women that schooling

${ }^{30}$ Knight, "Participation of Women", p. 197.

${ }^{31}$ Ibid.

32 Ibid

${ }^{33}$ Stites, Women's Liberation Movement, p. 166.

${ }^{34}$ Ruth Dudgeon, "The Forgotten Minority: Women Students in Imperial Russia, 1872-1917”, Russian History, 9 (1982), p. 9.

${ }^{35}$ Ibid., pp. 13-15; Stites, Women's Liberation Movement, pp. 175-177. 
had facilitated their political awakening, and therefore proved to be one of the most important forces for change in their lives. Thus, they did not differ significantly from their predecessors in the revolutionary movement of the 1870 s and 1880 s. $^{36}$

\section{Occupation}

In accordance with their high level of qualification, women social democrats formed a relatively homogeneous group in terms of occupation as well. Table 6 shows that prior to 1905 , the female party membership was composed of a negligible number of sluzhashchie (clerks, and other whitecollar workers); a quarter of the women were artisans or unskilled workers, but, by far, most of them were members of the intelligentsia and were almost equally divided between professionals (37\%) and students (34\%) (column A). The occupational background of social-democratic men, in contrast to this, revealed a clear trend towards proletarianization (column B); artisans and unskilled workers formed the largest group, followed by the $20 \%$ of students, while only $10 \%$ of male party-members were drawn from the intelligentsia. Lane came to the conclusion that the RSDRP was "predominantly a 'working-class' party", ${ }^{37}$ but that was based on an analysis which did not consider the characteristics of males and females separately: his conclusion is clearly wrong with regard to the occupational composition of social-democratic women.

Unfortunately, our pre-1905 sample of local leaders is quite small, since information on occupation could not be obtained in more than half of all cases. This may in fact suggest that many of the "unknowns" were professional revolutionaries, and these would probably have worked in one of the professions typical of the intelligentsia in their previous non-political life. One may therefore assume that the percentage of intellectuals among the local leaders was actually higher than is suggested by our data, and, accordingly, that female artisans and unskilled workers may have been represented to an even lower degree among local leaders. Nevertheless, there were cases of women, like Tsetsiliia Bobrovskaia or Mariia Essen, for example, who were workers by profession but who soon excelled as professional revolutionaries in leading positions.

As is evident from Knight's pre-1917 sample ( $N=116)$, no serious changes in the occupational composition of female RSDRP-members occurred after $1905 .{ }^{38}$ Our sample, based on the 1930 edition of Politicheskaia Katorga i Ssylka was somewhat smaller $(\mathrm{N}=69$, see column D), and the

${ }^{36}$ Kappeler, "Charakteristik russischer Terroristen", p. 538.

${ }^{37}$ Lane, Roots of Russian Communism, p. 21

${ }^{38}$ Knight, "Participation of Women", p. 198. 


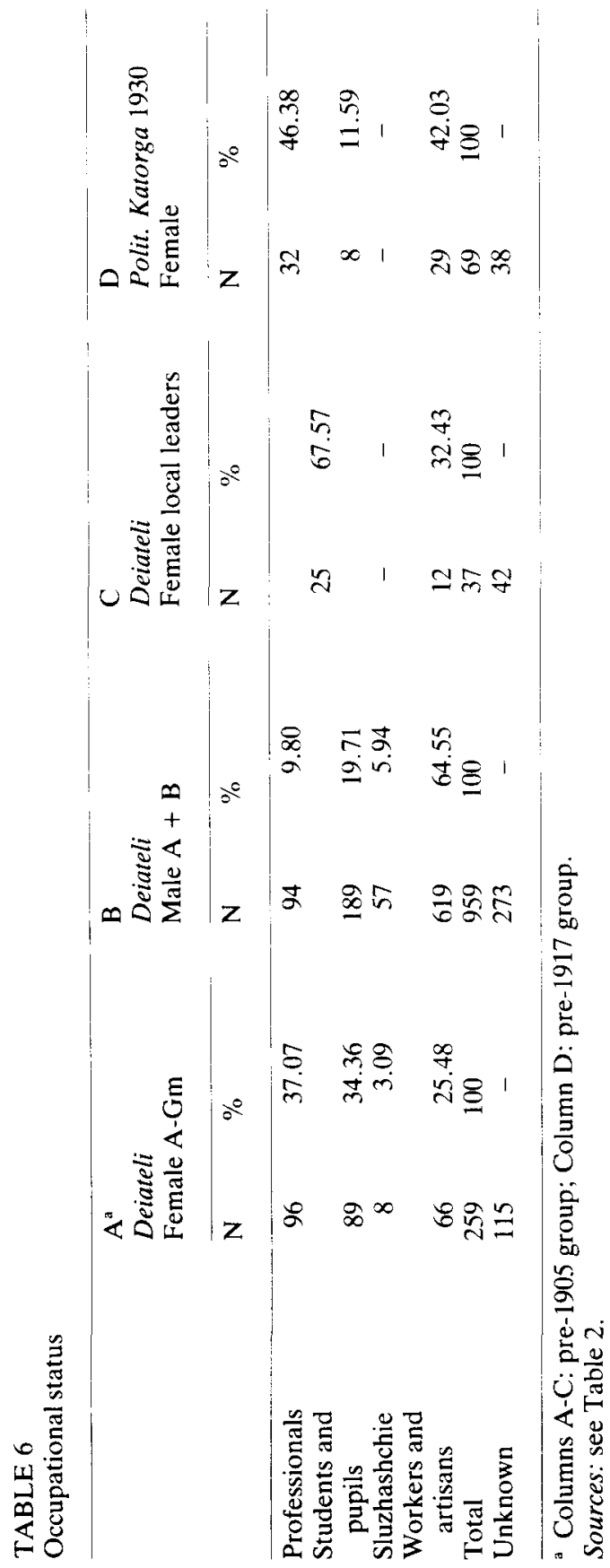


percentages given here tend to overestimate the proportion of artisans and unskilled workers, because the "unknowns" have been excluded; we should not take these data completely at face value therefore. The nonresponse of so many people with regard to occupation may have been caused either by students or by the intellectuals, who wanted to keep their intellectual background secret. If we assume that most of those who preferred to remain silent indeed belonged to the intelligentsia, then our data fall into line with the results of Knight's analysis.

Socialist revolutionary women exhibited characteristics similar to women RSDRP members ${ }^{39}$ with the exception that local leadership positions were rarely filled by manual workers.

Having analyzed the non-political occupations of social-democratic women more closely, it turned out that the majority of them were listed as minor medical personnel (midwives, feldshers, and dentists) or as teachers. Why is it that so many women working in the medical profession or in the field of education nurtured radical inclinations? Most graduates went into teaching because of the paucity of other options; there they received low pay and had to abstain from marriage or face dismissal. ${ }^{40}$ Given these conditions, it is not hard to imagine that they enthusiastically took up the social-democratic cause and left their classrooms in order to teach revolution in evening or Sunday schools for factory workers. Similarly, socialist revolutionary women had a stronghold among village teachers. It emerges that occupational frustration rather than failure accounted for the large number of minor female intellectuals who joined the RSDRP prior to 1917 and who even served as professional revolutionaries. Women doctors, pharmacists and chemists were markedly absent from the occupational spectrum of female social democrats however. Compared with the minor intelligentsia, they may have encountered fewer obstacles in their professions and they were therefore less likely to exchange a career for a life underground, or emigration.

The increasing industrialization of Russia was reflected in the occupational composition of male party members, but an equivalent trend manifested itself only hesitantly among females. Although the numbers and percentages of women factory-workers had begun to increase since the $1890 \mathrm{~s},{ }^{41}$ their proportion within the ranks of the RSDRP had stagnated. Although in 1905 about $60 \%$ of the party's members were from the working class, and though women accounted for almost $30 \%$ of the industrial labour

39 Ibid.

${ }^{40}$ Dudgeon, "Forgotten Minority", p. 11: Christine R. Hinshaw, "The Soul of the School. The Professionalization of Urban Schoolteachers in St. Petersburg and Moscow, 1890-1907' (Ph.D., University of California, Berkeley, 1986).

${ }^{41}$ Rose L. Glickman, Russian Factory Women. Workplace and Society, 1880-1914 (Berkeley, 1984), pp. 84-85. 
force,$^{42}$ yet they only made up $7.2 \%$ of the party membership..$^{43}$ Nevertheless, the occupational characteristics of female manual workers, who were concentrated presumably in the textile and other light industries, mirrored itself in the RSDRP. In all the branches which indicated occupational characteristics, textile workers figured prominently, followed closely by artisans in similar trades (seamstresses, stocking knitters and corset makers), most of whom were employed in small sweatshops. All these women worked in enterprises which had a preponderantly female labour force, and through the networks which developed between them they provided a supportive milieu for the process of radicalization. ${ }^{44}$ Despite some modest changes taking place at the grass roots level among women workers, they did not support the RSDRP in large numbers prior to 1917 however. As long as the process of "proletarianization" did not alter the composition of the female party membership, it would remain a homogeneous group composed mainly of intellectuals.

\section{Nationality}

Table 7 shows the nationalities of both male and female RSDRP members. As is apparent from this table, approximately one half of the pre-1905 sample of women social democrats were of Russian origin; the other half consisted mostly of Jews and small groups of Ukrainian, Polish and German women (column A). Russians formed the largest national group among male party-members as well, followed by a large Jewish contingent and minor Ukrainian, Georgian and Armenian minorities (column B); there is a suggestion here of a greater variation in their ethnic composition than in that of the all-female group.

In the pre-1917 sample the percentage of Jewish women was somewhat lower, while more women of Latvian or German origin had joined the RSDRP (column D). As is evident from Knight's survey, the percentage of men who were Jewish had decreased to an even greater extent. ${ }^{45}$ Unfortunately, we do not know whether this reduction was due to the fact that people of Jewish origin left the RSDRP in favour of the Jewish Bund, or whether it resulted from an influx of mostly Russian social democrats after 1905. Despite these losses, Jews remained disproportionately represented among both males and females in the RSDRP since the Jewish population

${ }^{42}$ Ibid., p. 83.

43 V.V. Lozhkin, "Sostav Rabochikh Sotsial-Demokratov i ikh Rol v Sozdanii Leninskoi Partii”, Voprosy Istorii, 7 (1983), pp. 70 and 75.

44 Anne L. Bobroff, "Working Women, Bonding Patterns, and the Politics of Daily Life: Russia at the End of the Old Regime" (Ph.D., University of Michigan, 1982), pp. 686-751.

${ }^{45}$ Knight, “Participation of Women”, p. 198. 

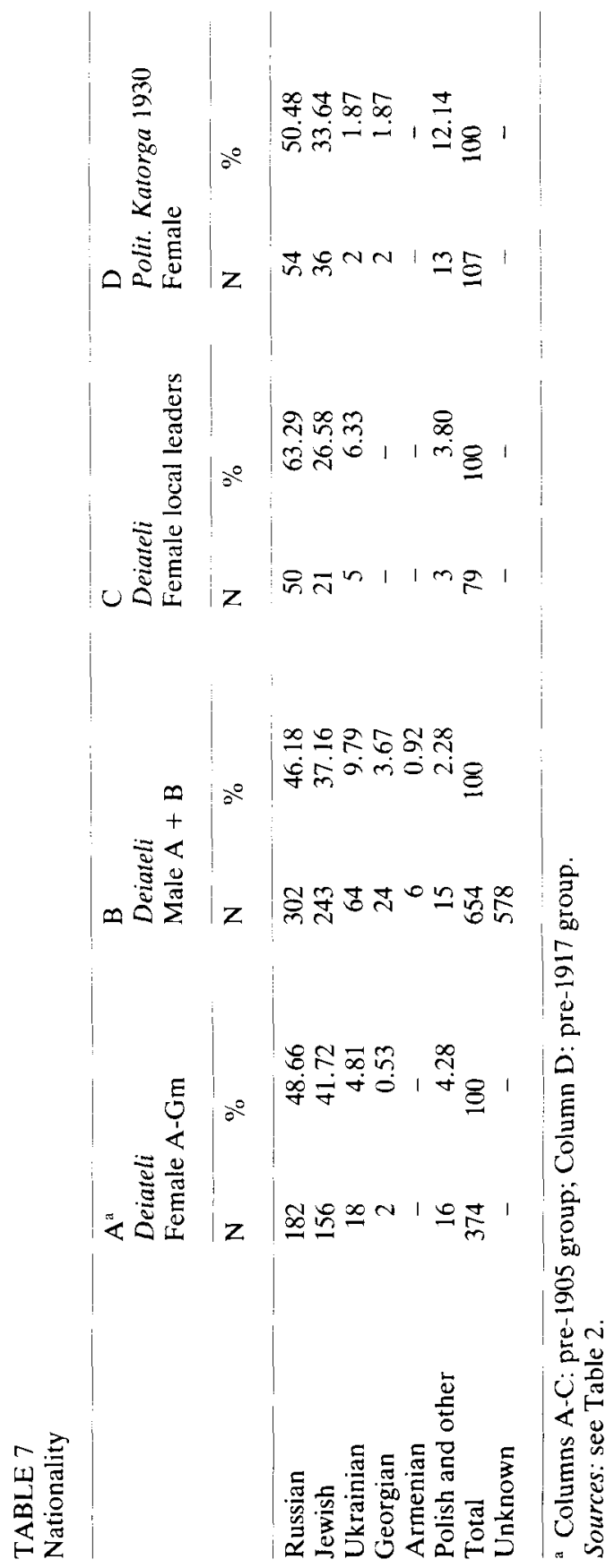
accounted for only $4 \%$ of the entire population of the Russian Empire. ${ }^{46}$ Their high degree of political activism, which was also well reflected in the PSR,${ }^{47}$ might be attributed to the experience of persecution and suppression. Not only popular anti-Semitism, but also the legal disadvantages which confined them to certain areas or the numerous restrictions they faced in trying to enter institutions of higher learning, certainly facilitated the development of radical inclinations. A further explanation is that the Jewish minority in Imperial Russia constituted a highly urbanized and literate group which could easily be reached by political propaganda. But what accounted for the overwhelming appeal which social democracy exercised on Jewish women? Nearly $35 \%$ of women RSDRP members in pre-1917 Russia were Jewish, and this percentage was double that of Jewish men. ${ }^{48} \mathrm{~A}$ similar preponderance of Jewish women had been characteristic of the narodnik and terrorist organizations of earlier decades. ${ }^{49}$ Jewish girls usually received secular schooling and were therefore more likely to come into contact with radical ideas or illegal literature than their brothers, who were sent to study in Talmud schools. Accordingly, Jewish women were far more likely than men to enrol in university courses. ${ }^{50}$ This might also be an indication of their desperate need to break free from the proverbial narrowness of the shtetl and to acquire knowledge instead. The patriarchal structure of Jewish family life might also have played an important role. Girls more often than not had to endure arranged marriages and the despotism which accompanied this tradition. It is clear that Jewish women tended to combine their emancipation as Jews with their liberation as women. It should be pointed out, however, that a great proportion of social-democratic women of Jewish background originated from assimilated urban milieus, in which the strict customs of orthodox Jewry had already withered away along with the mastery of the Yiddish idiom.

If we assume that the sample of pre- 1905 female local leaders reflects the true composition of the inner party (column C), then it emerges that Jewish women had considerably fewer chances of rising to the level of local leader than Russian women had, who were markedly overrepresented at this level. As Knight's data suggest, this pattern was still evident up to 1917, but it had weakened somewhat in favour of the Jewish minority. ${ }^{51}$

Prior to 1917, neither the RSDRP nor the PSR were successful in attracting large numbers of women with other than Russian or Jewish back-

46 Hugh Seton-Watson, The Decline of Imperial Russia, 1855-1914 (London, 1964), p. 31.

${ }^{47}$ Knight, "Participation of Women", p. 198.

48 Ibid.

${ }^{49}$ Stites, Women's Liberation Movement, p. 150.

so Dudgeon, "Forgotten Minority", p. 16.

s1 Knight, "Participation of Women", p. 198. 
grounds.$^{52}$ Women living in the most backward parts of the Russian Empire did not espouse the cause of social democracy before substantial changes had already been brought about in their lives after the October revolution.

\section{Factional differences}

Factional allegiance was given in Deiateli for only forty-seven female social democrats out of all 374 women listed. Twenty-eight of these were members of the Bolshevik faction, the remaining nineteen were Mensheviks. In view of the paucity of this material it is hardly suited to presentation in tabular form; nevertheless, differences in the social composition of the female membership of both wings of the RSDRP should not go unmentioned.

The main characteristics of the typical social-democratic woman, such as the upper social background, high educational and occupational levels, as well as a Jewish background were especially common among female Mensheviks. Only in terms of age and revolutionary experience did Menshevik women differ from the all-female group; they tended to be older and to have more experience as revolutionaries, for quite a few of them had already been involved in the narodnik movement. These findings are in agreement with the factional differences which Knight has established for the pre-1917 group. ${ }^{53}$ According to her sample based on sixty-six Bolshevik and twenty-five Menshevik women, the social characteristics of the Menshevik female group closely resembled those of the socialist revolutionary women. The male majority of the PSR, on the other hand, was more similar to the Bolshevik faction of the RSDRP. ${ }^{54}$

Summing up the development of female RSDRP membership from the beginnings of the social-democratic movement to 1917 , we might conclude that these women - as a group - shared certain well-defined characteristics which set them apart from male party members. The average "sotsialdemokratka" was of meshchanstvo origin, had received at least a secondary education and worked in the minor intelligentsia-professions, presumably as a teacher. Female social democrats proved to be more homogeneous as a group than male party members, and this was especially true with regard to their ethnic origins.

These findings suggest that any statement concerning the social composition of Russian social democrats must take into account significant differences between its female and male membership. Most of the common notions about the RSDRP as a whole are in fact only valid for its male

52 Ibid.

53 Ibid., pp. 203-205.

${ }^{54}$ Perrie, "Social Composition and Structure", p. 249. 
majority, and therefore tend to obscure completely the typical features of women social democrats. It appears from this survey that female RSDRP members closely resembled socialist revolutionary women with regard to social composition. What is more surprising though is that the typical characteristics of female revolutionaries had not substantially changed since populism was at its peak. The major difference was in size of female participation. The social structure of women social democrats tended to point backwards rather than reflect the process of modernization taking place in the Russian Empire. Despite these changes, women still needed a high social and educational level in order to compensate for their inferior position and their low status in Russian society. Nevertheless, the revolutionary year 1905 marked a turning point from which time on the social composition of female party members began to change, however slowly and modestly when compared with that of men.

If we consider women's collective experience as reflected in their memoirs this will give a clearer understanding of how many cultural barriers they had to overcome before they would join the ranks of the RSDRP. Since not many of them left a body of theoretical or literary work, it is impossible to grasp them as people by interpreting their ideas however. What is possible though is to reconstruct the female road to radicalization and to follow their political awakening step by step.

In contrast to Anzhelika Balabanova, who thought of herself as a born rebel, ${ }^{55}$ the recollections of most Russian women social democrats suggest that they were not endowed with an innate revolutionary temperament but rather slowly developed radical leanings. After all, they grew up at a time when public life in Russia was full of intense debates and stirring with radical ideas; traditional concepts of femininity slowly began to change; new educational, professional and even political opportunities for women opened up which might have facilitated the decision of young women to transcend the traditional limits of womanhood and to take on unconventional roles instead.

Most female party members of the first generation, like, for example, Krupskaia, Tsederbaum, Broido, Lepeshinskaia, and Samoilova, came into contact with social-democratic groups during their years of study; in the academic milieu of the capital or in other big cities they read political pamphlets and newspapers or became personally acquainted with members of so-called circles of "self-education". Soon they were drawn into these groups themselves where they started to "work out a Weltanschauung" based upon the socialist theories of the time. The second and third generations of women social democrats were radicalized at an earlier age; grow-

${ }^{5 s}$ A. Balabanoff, Erinnerungen und Erlebnisse (Berlin, 1927), p. 7; A. Balabanoff, My Life as a Rebel (New York, 1938), p. 4. 
ing up in the atmosphere of approaching revolution, they had already joined political circles while still schoolgirls - a risky thing to do, for it could lead at best to being denied the gold medal or at worst to expulsion from school because of political unreliability. Some were thus turned into "politicals" even before they had reached maturity. ${ }^{56}$

Despite the many similarities in the radicalization of male and female social democrats, there were important differences as well. A young girl in Tsarist Russia who made up her mind to study had to cope with difficulties unknown to male students. First, it meant taking an unconventional decision not necessarily welcome to their families. Second, there were very few institutions inside Russia where women could acquire a higher education at all. ${ }^{57}$ During the years 1886 to 1900 , when the first and second generations of women social democrats had finished their secondary education, all Higher Courses for Women, except for the "Bestuzhevskie Kursy" in St. Petersburg, ${ }^{58}$ had been discontinued after only a few years of their existence.

It required a lot of strength and a strong will - in addition to the gold medal from school - before a girl could have her own way and become a kursistka. Prejudice, or simply fear, led parents to oppose the ambition of their daughters, who needed parental permission in order to enrol. As a consequence, some women broke up with their families completely and tried to make it on their own; others had to struggle with their parents for years before they let them go. ${ }^{59}$ Some who could afford it went abroad (preferably to Belgium or to Switzerland) and took courses with wellknown socialist professors; when they returned to Russia as "fully devel-

${ }^{56}$ S. Dzerzhinskaia, V Gody Velikikh Boev (Moscow, 1965), p. 12; O. Lepeshinskaia, Put v Revoliutsiiu (Perm, 1963), p. 23; L. Manuilova, Pechali i Radosti Moei Zhizni (Moscow, 1922), p. 24; V. Serge and N.S. Trotsky, The Life and Death of Leon Trotsky (London, 1975), p. 12; Ia. Naumov, Chekistka. Stranitsy iz Zhizni Zamestitelia Predsedatelia Kazanskoi Gubcheka V.P. Braude (Moscow, 1963), pp. 29-48.

${ }^{57}$ For the history of women's higher education in Russia see: R. Dudgeon, "Women Students in Russia, 1860-1905" (Ph.D., George Washington University, 1975); C. Johanson, Women's Struggle for Higher Education in Russia, 1855-1900 (Kingston, 1987); S. Satina, Education of Women in Pre-Revolutionary Russia (New York, 1966). 58 J.C. McClelland, "Bestuzhev Women Courses", in J.L. Wieczynski (ed.), Modern Encyclopedia of Russian and Soviet History, 4 (1977), pp. 101-102; C. Johanson, "Higher Courses for Women", idem, 14 (1979), pp. 50-52.

${ }^{59}$ Ia. Zemkova and E.T. Zorina, "Vsegda Byla Bolshevikom", in Ts.V. Zorina, A.I. Nukhrat, A.M. Kharkova (eds), Revolutsionerki Rossii (Moscow, 1983), p. 30; Balabanoff, My Life as a Rebel, pp. 10-11; Lepeshinskaia, Put v Revoliutsiiu, p. 24; A.S. Kurskaia, Perezhitoe (Moscow, 1965), p. 14; L. Loiko, Ot Zemlii $i$ Volii $k$ VKP $(b)$, 1877-1928. Vospominaniia (Moscow, 1929), pp. 19-20; B.N. Jakowlewa, Lebenslauf einer Bolschewikin (Moscow, 1934), p. 9; A. Kollontai, "Avtobiograficheskii Ocherk", Proletarskaia Revoliutsiia, 1 (1921), p. 261; L. Tsederbaum-Dan, "Semia. I-z Vospominanii”, in: Boris Sapir (ed.), Iz Arkhiva L.O. Dan (Amsterdam, 1987), pp. 13-14. 
oped socialists", they would join the revolutionary movement as soon as possible. ${ }^{60}$

The kursistki inside Russia, however, gained their political training in informal student circles. For many of them these circles marked the first step into a serious and permanent revolutionary involvement. Others were drawn into radical activity as participants in student demonstrations, especially in the course of the "Vetrova-affair" (1895). Vetrova, a student of the Bestuzhev courses and a populist activist, had been jailed because of illegal activities and had committed suicide in the Peter-and-Paul-Fortress. Bestuzhevki, like Lidiia Tsederbaum, Praskovia Kudelli and Konkordiia Samoilova, helped organize student meetings and demonstrations, and they wrote a pamphlet in memory of Vetrova, protesting against her death under obscure circumstances. This experience left a profound emotional impression upon them, and it triggered their deeper involvement in revolutionary politics. Their future lives were to be devoted to taking revenge for martyrs like Vetrova. ${ }^{61}$

Illegal activities did not remain unnoticed though, and many a "studentka" was expelled from their courses ${ }^{62}$ Even though one should not exaggerate the extent to which these young women were active in the political underground, ${ }^{63}$ it remains a fact that some of them turned to a full-time revolutionary commitment as social-democratic agents only after their planned course of education had been deprived them. Others simply forgot about earning a degree or having a professional career; they left the courses voluntarily, sometimes spontaneously, and threw themselves wholeheartedly into political work. ${ }^{64}$ After they became deeply infected by the "revolutionary bacilli" widespread in the academic air, they longed to dedicate themselves fully to the "radical curriculum", instead of pursuing an academic training. Nevertheless, the majority of women students in Russia did not engage in politics and remained purely "academics".

Not all future women social democrats came from well-to-do families who could afford a secondary and higher education for their daughters. Party members from lower social strata, especially if they were female,

${ }^{60}$ Balabanoff, My Life as a Rebel, p. 15; A. Kollontai, Autobiographie einer sexuell emanzipierten Kommunistin (Vienna, 1975), pp. 17-18; J. Fréville, Une Grande Figure de la Révolution: Inessa Armand (Paris, 1957), pp. 40-42.

${ }^{61}$ S.N. Valk (ed.), Sankt-Peterburgskie Vysshie Zhenskie Kursy, 1876-1918 (Leningrad, 1965), pp. 29-32; P.F. Kudelli, Pamiati M. Vetrovoi (n.p., 1898); Stites, Women's Liberation Movement, p. 173; B. Sapir, "Lidiia Osipovna Dan. Biograficheskii Ocherk", in: Iz Arkhiva L.O. Dan, p. XIX.

${ }^{62}$ G. Mishkevich, Konkordiia Nikolaevna Samoilova (Leningrad, 1947), p. 4; S. Dubnova-Erlikh, Obshchestvennyi Oblik Zhurnala 'Letopis', Inter-University Project on the History of the Menshevik Movement, Paper No 14 (New York, 1963), p. 2.

${ }^{63}$ Compare, for example: Serge and Trotsky, Life and Death of Leon Trotsky, p. 12.

${ }^{64}$ N.N. Aladzhalova, Iz Bolshevistskogo Podpolia. Vospominaniia (Tbilisi, 1963), p. 5. 
more often than not were denied a formal education. However, they did not remain illiterate and either taught themselves to read and write or they attended courses at Sunday or evening schools for workers. Even though they read unsystematically and without recommendations from their elders, they slowly became familiar with the same literary canon as women from well-educated families, where liberal or even progressive tendencies prevailed and where the "thick journals" were held. Devouring every book - mostly novels - they could borrow from public libraries or acquaintances, ${ }^{65}$ they read Turgenev's novels as well as Chernyshevskii's famous What is to be done?, and tried to emulate their heroines. It is unquestionable whether this literature influenced generations of Russian revolutionaries; what is striking though, is the fact that not a single woman social democrat (all of whom seem to have read, or at least known Chernyshevskii's book felt attracted by the feminist aspects of the novel. As with marxism, it was obviously not a theoretical approach to the "woman question" that made them turn to socialism.

Women who left their proletarian or traditional Jewish milieus in order to join the social-democratic movement did so after extensive reading had stimulated a desire in them to leave their homes, to learn more, and to escape from provincial narrowness. ${ }^{66}$ Some of them even took for reality what was described in Chernyshevskii's fiction. ${ }^{67}$ At first, their reading had served as a substitute for attending school ${ }^{68}$ - a dream which had not come true for most girls of poor origin, because their help was needed in the house, or because they had to take care of their younger brothers and sisters. ${ }^{69}$ Later they realized that the ability to read and write was just a precondition for liberation. In the course of breaking free from their traditional milieu so limited in scope, they too were drawn into selfeducation circles, where they were usually instructed by students.

In these circles future women social democrats came into contact with socialist philosophical or political writing for the first time in their lives. Of the texts they remember having thoroughly studied, most women mention

${ }^{65}$ C. Bobrowskaja, Die ersten zwanzig Jahre. Aufzeichnungen einer alten Bolschewikin (Zurich, 1934) p. 6; M. Essen, Pervyi Shturm (Moscow, 1957), p. 12.

${ }^{66}$ E. Broido, Wetterleuchten über Rußland (Berlin, 1977), p. 14; E. Broido, V Riadakh RSDRP (Moscow, 1928), pp. 12-13; Kurskaia, Perezhitoe, p. 8; Jakowlewa, Lebenslauf einer Bolschewikin, p. 7; Lepeshinskaia, Put v Revoliutsiiu, p. 5.

${ }_{67}$ Bobrowskaja, Die ersten zwanzig Jahre, p. 7; Ts. Bobrovskaia, Zapiski Podpolshchika 1894-1917 (Moscow, 1957), p. 4; Manuilova, Pechali i Radosti, p. 21; Essen, Pervyi Shturm, p. 14.

${ }^{68}$ E. Riskind, "Na Zare Sotsial-Demokraticheskogo Dvizheniia v Charkove", Letopis Revoliutsii, I (6) (1924), p. 88; S. Markovskaia, Istoriia Odnoi Rabotnitsy (Moscow, 1929), p. 7.

${ }_{69}$ L. Volshtein, "Zapiski Fabrichnoi Rabotnitsy", Proletarskaia Revoliutsiia, 9 (1922), p. 162; “A.K. Naglin”, Katorga i Ssylka, 39 (1928), p. 170. 
Plekhanov's works, the Erfurt programme of the German social democrats, and Bebel's famous study on Woman under Socialism. To accept these reminiscences at face value is to believe that all circles went through all three volumes of Das Kapital by Marx - even though most women admitted that this reading caused serious problems: "It was difficult, but we did not give up." ${ }^{70}$ Other female party members conceded that in the beginning they could hardly grasp the differences between populism and marxism, or that they were unable to distinguish between different political groups. ${ }^{71}$ This difficulty may be explained if we remember that these "kruzhki" (circles), a phenomenon typical of the 1890 s, were not strictly separated into those of socialist and others of populist orientation. On the contrary, adherents of both ideologies worked closely together at the local level and the circles did not produce fully-developed ideologists of various types but instead left their members with a "Weltanschauung" that was an eclectic mixture of all political trends that were in vogue at that time. The writings of Marx and Bebel were widely read, not only by socialists; they constituted an integral part of good populist or even feminist political education. ${ }^{72}$ However, the 1890 s were the decade of marxism, whereas populism was declining. Especially among young people, it was considered "chic" to be a marxist.

It is fruitless to check memoirs of social democratic women for political arguments that could explain why they favoured social democracy rather than populism. Often it was a matter of chance whether they entered the social-democratic or the socialist revolutionary parties. Sometimes only social-democratic groups were available at the local level; sometimes relatives or acquaintances who considered themselves social democrats recruited women for the movement.

Personal relations with male social democrats seem to have played a crucial role in the decision of women to enter the party. This is true for women from all social strata. They were either influenced by male students (often relatives) or by "class-conscious" fellow-workers. Unfortunately, there are hardly any surviving recollections of women who turned to social democracy before 1917 as former members of other political parties. Women like Knipovich, Kudelli, and Zasulich, who belonged to an older gener-

${ }^{70}$ Essen, Pervyi Shturm, p. 21.

71 "Z.I. Lilina, "Lilina o Samoi Sebe. Avtobiografiia", Krasnaia Letopis, 4 (3) (1929), p. 245; Broido, V Riadakh RSDRP, p. 14; Bobrovskaia, Zapiski Podpolshchika, p. 22; Lepeshinskaia, Put v Revoliutsiiu, p. 34.

${ }_{72}$ The "Soiuz Ravnopravnosti Zhenshchin", for example, recommended the writings of Bebel in his Ukazatel Vazhneishikh Sochinenii po Zhenskomu Voprosu (Moscow, 1907); L. Akselrod, "Iz Moikh Vospominanii", Katorga i Ssylka, 2 (63) (1930), p. 26; R. Pipes, "Russian Marxism and its Populist Background: The Late Nineteenth Century", The Russian Review, XIX (1960), p. 230; E.D. Kuskova, "Davno Minuvshee", Novyi Zhurnal, 50 (1957), p. 185. 
ation, had quite naturally been active in the populist movement in earlier decades. But then, disappointed with its failure or disillusioned with terrorism, they slowly developed marxist inclinations and thus came to form the first generation of Russian social democrats. Others, like Drabkina or Sokolovskaia, who joined the cause of social democracy later, did not give political reasons for their change of mind. Full of justifications, their biographies or memoirs have not much to say other than that they were mistaken in their political judgement before. ${ }^{73}$

Though memoirs of socialist-revolutionary women have not been analyzed systematically, it does seem that their radicalization shows the same pattern as that of social-democratic women, except that they were more attracted by the revolutionary activism of this party, in contrast to the theoretical orientation of the RSDRP. This was true, on a minor level, for women social democrats, as well. Most female party members did not spend much time studying or discussing marxist literature. As soon as they were drawn into illegal activities, they either lacked time for further serious intellectual training, or, more often, they preferred practical deeds to theoretical debate. Brobovskaia, for example, wrote: "Let me confess that I was more interested in the fact that we did publish leaflets than in their contents." 74 Akselrod made a similar remark: "I personally was much more satisfied working with a small group of stocking weavers than reading the first chapter of Das Kapital with intellectuals." ${ }^{75}$ Similar statements are not to be found in recollections of male professional revolutionaries - except if they were written by party workers of proletarian origin. Accordingly, women social democrats constantly emphasize in their memoirs that they felt incompetent or insufficiently prepared for party work. It is striking that they regarded themselves as being less educated than their male colleagues. As a consequence, they seldom took an active part in discussions, but sat aside, silently listening, admiring. ${ }^{76}$ In contrast to men, female party members described their becoming a social democrat as something emotional, as a process of inner self-stabilization after a difficult period of ideological disorientation. Their understanding of socialism came across more as an attitude than a way of thinking. Only a few women gave us a definition of

${ }^{73}$ S.F. Vinogradova, E.A. Giliarova, M.Ia. Razumova (eds), Leningradki. Vospominaniia, Ocherki, Dokumenty (Leningrad, 1968), pp. 97-100; I.I. Mints and A.P. Nenarokov (eds), Zhenshchiny - Revoliutsionery $i$ Uchënnye (Moscow, 1982), p. 126; V.G. Konovalov, Elena (Odessa, 1969), p. 13; Manuilova, Pechali i Radosti, p. 90.

${ }^{74}$ Bobrovskaia, Zapiski Podpolshchika, p. 15.

75 Akselrod, "Iz Moikh Vospominanii", p. 42.

${ }^{76}$ N. Krupskaja, Erinnerungen an Lenin, 2 vols (Berlin, 1926-1929), vol. 1, pp. 5-6; S. Nevzorova-Shesternina, "Stranichka Vospominanii", in Vospominaniia o V.I. Lenine, 3 vols (Moscow, 1956-1961), vol. 1, p. 142; R. McNeal, Bride of the Revolution: Krupskaia and Lenin (Ann Arbor, Michigan, 1972), p. 303. 
what marxism meant to them and why they had found it to be attractive. Krupskaia said, for example: "Marxism meant the greatest happiness. To know where you have to go, to be sure about the happy ending of the cause with which your life is from now on linked." "77 Even Akselrod and Balabanova, who were interested in the philosophical roots of marxism, stressed that it was the ethical and moral qualities that fascinated them in marxist ideology.

Not a single female social democrat mentioned socialist theory in relation to the emancipation of women. Thus, according to their memoirs, women did not enter the RSDRP because the party programme favoured the equality of the sexes. On the other hand this certainly does not mean that their own experience as women did not facilitate at all their decision to join the social-democratic movement.

What have been described so far as important steps in the radicalization of Russian social-democratic women seemed to be typical for the first generations of female as well as of male Russian marxists. Their political culture, their basic literary canon, looked more or less identical. They even shared role models, heroes and ideals. However, women as a group were driven by motivations and goals which set them apart from their male "tovarishchi" and which could be called gender-specific.

As we have seen, for most women social democrats the decision to study personally marked a more radical break with the past than their joining the RSDRP. Once enrolled as students, it was very likely that they would be radicalized and it happened somehow naturally, subconsciously. Their decision to study, however, reflected not so much a desire for learning or a thirst for knowledge in a scholarly sense. Most autobiographies do not even tell us which subjects they chose, nor do they say whether they ever finished their courses and graduated. To be a "kursistka" apparently meant something different: being independent, leading an autonomous, full life. It meant breaking free from parental control, leaving behind provincial boredom and the monotony of everyday life. Living in the capital and sharing an apartment with other students appealed to them as marking the definite end to a protected childhood and the beginning of a new, adventurous period in life. When they travelled to the "big city", most often unaccompanied for the first time in their lives, they were in a euphoric mood. Nevzorova, for example, remembered: "In the sunny and frosty morning of October 1893, I went to Piter. Finally it had come true, what $I$ had dreamt of for years. Finally I was in Piter, a student of the Higher Courses for Women. My heart

7 N. Krupskaia, "Kak Ia Stala Marksistkoi”, in N. Krupskaia, Pedagogicheskie Sochineniia v Desiati Tomakh, 10 vols (Moscow, 1960-1963), vol. 1, pp. 34-35; compare, as well: A.A. Berezina, in V.P. Fadeev (ed.), Vospominaniia Nizhegorodtsevo V.I. Lenine (Gorki, 1960), p. 53. 
was beating with joy and I could hardly believe my great luck." ${ }^{78}$ A more resolute woman like Lepeshinskaia, who had already planned the further course of her life in detail, remembered the beginnings of her studies from a more detached perspective: "I went away in order to study. Afterwards I would go back to my town in order to help those, who were dependent on my knowledge as feldsheritsa, poor, miserable people. I only wanted one thing: to be useful.,"79 This desire to be useful, "sluzhit narodu", may be listed as the second main motivation for a girl's decision to study. It was strong enough to make her accept material deprivation and conflict with her parents.

Those women, however, who were still looking for a task in life, soon became disappointed with what the courses had to offer. Krupskaia wrote: "I noticed that the courses did not provide me with what I was looking for. I got to know many learned things but only very little that could be used in real life. $"{ }^{80}$ It did not therefore cause much inner turmoil for women like Krupskaia to give up the courses altogether for something they considered more promising: the revolutionary movement. A lack of orientation, and isolation, were typical for many women social democrats when they took up their studies. They had high expectations, which were simultaneously diffuse and abstract. But they were fully aware of this and regarded themselves as 'seekers'. Depending on their character and temperament this mood left them either curious or rather depressed: "Unclear and uncertain was my longing for knowledge, for free development of my personality, but it was so general that the ridiculous attribute 'a young girl with strivings' became a characteristic phrase." ${ }^{81} \mathrm{Or}$, another variant: "In a word, I floundered about helplessly." 82 As soon as these young women joined political student circles, their depressed mood gave way to revolutionary enthusiasm. Vague plans for the future filled with concrete political goals and prompted them to join the RSDRP.

The desire of future women social democrats to lead an interesting life can be interpreted not only as a youthful awakening in general, but also as a reluctance to succumb to the traditional roles assigned to women in late Imperial Russia. Even though not all of them depicted their childhood as deeply unhappy and oppressive, they all stated in their recollections the extent to which they, as girls, were excessively sheltered and more restricted than their brothers. Depending on the material well-being of the family

${ }_{78}$ Nevzorova-Shesternina, Stranichka Vospominanii, p. 24; Balabanoff, My Life as a Rebel, pp. 2-3; Valk, St. Peterburgskie Vysshie Zhenskie Kursy, pp. 242 and 280.

${ }^{79}$ Lepeshinskaia, Put v Revoliutsiiu, p. 24; N. Kolesnikova, Po Dorogam Podpolia. Vospominaniia (Baku, 1966), p. 5; Kurskaia, Perezhitoe, p. 14.

${ }^{80}$ N. Krupskaia, Mein Leben (Berlin, 1925), p. 15.

${ }^{81}$ Broido, V Riadakh RSDRP, p. 14.

${ }^{82}$ Quoted in: C.S. Bobrovskaya, Lenin and Krupskaya (New York, 1940), p. 6. 
they were either supposed to marry and "make a good match" or to become governesses. They rebelled at both suggestions. To escape this fate required hard struggle; it drove Zasulich or Kuskova, for example, to the verge of committing suicide. ${ }^{83}$ Some women were lucky enough to find strong female personalities in their families who provided them with important models of nontraditional active female behaviour. These could be nurses, teachers, or even mothers and sisters, who were successful as business women, poets or actresses.$^{84}$ Others tried to model their lives on those of their beloved father or brothers, whom they admired and whose equal they wished to be. The stimulating desire "to lead a man's life" is expressed in quite a few autobiographies by female social democrats. ${ }^{85}$

A significant number of female party members grew up in one-parent or even no-parent families, or under emotionally difficult circumstances; that is to say, many of them did not have the experience of a normal childhood.$^{86}$ Outsiders in the families of step-parents or relatives, they developed a strong sense of not belonging. Looking for a counterweight to this unhappy situation, they thought of themselves as having a mission to fulfill, as being predestined to reach something outstanding in life. Others simply were longing for comradeship or for a place for themselves in the world. The RSDRP, a closely-knit society of like-minded people dedicated to the same cause, did in fact function as a spiritual home and offered a social milieu that could replace what these women had lost or had never had.

Many women social democrats were also motivated by a social conscience which was not necessarily the result of personal experience. Rebellion against injustice and solidarity with the poor and oppressed, had manifested themselves already during their childhood and can be considered as an integral part of their turning to radicalism later. ${ }^{87}$ In the begin-

${ }^{83}$ V.I. Zasulich, Vospominaniia (Moscow, 1931), p. 15; E. Kuskova, "Davno Minuvshee", Novyi Zhurnal, 45 (1956), p. 174.

${ }_{4}$ A. Kollontai, Iz Moei Zhizni i Raboty (Moscow, 1974), p. 54; Balabanoff, My Life as a Rebel, p. 7; J. Stasova, Erinnerungen (Berlin, 1978), pp. 18, 21, 22; Lepeshinskaia, Putv Revoliutsiiu, p. 5; B. Farnsworth, Aleksandra Kollontai: Socialism, Feminism, and the Bolshevik Revolution (Stanford, California, 1980), p. 11.

${ }^{85}$ Kollontai, Iz Moei Zhizni i Raboty, pp. 67-68; Zasulich, Vospominaniia, p. 15.

${ }^{86}$ Broido, V Riadakh RSDRP, p. 10; Zasulich, Vospominaniia, p. 11; E. Rozmirovich, "Avtobiografiia", Entsyklopediia Bibliograficheskogo Instituta 'Granat', 41 (2), pp. 206-207; Dzerzhinskaia, V Gody Velikikh Boev, pp. 6-8; Manuilova, Pechali i Radosti, pp. 7-10; P. Garvi, "Krasnianskaia", in P. Garvi, Revoliutsionnye Siluety, Inter-University Project on the History of the Menshevik Movement (New York, 1962), p. 35; D. Konovalov, Saratovskii Agent 'Iskry' (Saratov, 1969), p. 13; A. Kruglova, Nezabyvaemoe. Vospominaniia (Leningrad, 1963), p. 8.

${ }^{87}$ Balabanoff, My Life as a Rebel, p. 4; Lepeshinskaia, Put v Revoliutsiiu, p. 7; Krupskaja, Mein Leben, p. 9; Kollontai, Autobiographie einer sexuell emanzipierten Kommunistin, pp. 13-14; Kollontai, "Avtobiograficheskii Ocherk", p. 261; L. Gromozova, Rech (Geneva, 1904), p. 2; E. Stasova, Stranitsy Zhizni i Borby (Moscow, 1957), pp. 20-21; Kolesnikova, Po Dorogam Podpolia, p. 5. 
ning it found an outlet in charitable or social endeavours, practical deeds. In contrast to their male party-comrades, most women social democrats worked without pay in Sunday or evening schools, in libraries and reading rooms for workers, they helped as medical personnel in "zemstva-organizations", they were active in the Political Red Cross or in the Mobile Museum of Pedagogical Aids, and nearly all of them volunteered as nurses or cooks in the campaigns against famine and cholera epidemics of 1891$92 .{ }^{88}$ Most of these charitable organizations depended heavily on the active participation and support of women, especially philantropically-oriented students. The social dedication of women social democrats did not stop as soon as they joined the movement; on the contrary, for quite a time they did not strictly separate charitable and political activity from one another.

Fewer future women social democrats were active in feminist organizations. Except for a few Bolsheviks and Mensheviks who were members of the "Soiuz Ravnopravnosti Zhenshchin" for a short time, the majority of female party members shared a view that regarded feminist separatism as a dangerous, bourgeois diversion from the common cause. ${ }^{89}$

As we have seen, it did not provoke much anguish when it came to giving up studying or leaving a job for the sake of a revolutionary vocation. Just the opposite was true, though, when women had to decide between conventional family life and party work. Some female social democrats, for example Rozmirovich, Kollontai, Tsederbaum, were married before they joined the party. Getting divorced was to leave a painful mark in their lives. ${ }^{90}$ As far as their private life is concerned, authors of memoirs usually kept it so private that it is hard to discern whether they were married or not, or whether they had children. Only occasionally were husbands and children mentioned. As a rule, women social democrats tended to marry party members active in the same faction, and mixed couples like that of the Bolshevik Flakserman and the Menshevik Sukhanov were a rare exception. Comradeship marriages permitted one to combine both wishes: under-

${ }_{88}$ Zasulich, Vospominaniia, p. 16; Loiko, Ot Zemlii $i$ Volii $k$ RKP(b), pp. 16-17; Dzerzhinskaia, V Gody Velikikh Boev, p. 15; Kuskova, "Davno Minuvshee", Novyi Zhurnal 49 (1957), p. 150; Stasova, Stranitsy Zhizni i Borby, pp. 21-23; N. Krupskaia, "Piat Let Raboty v Vechernikh Smolenskikh Klassakh", in Pedagogicheskie Sochineniia $v$ Desiati Tomakh, 1, pp. 38-55.

${ }^{89}$ P. Podliashuk, Tovarishch Inessa (Moscow, 1963), p. 14; Z.V. Grishina, "Dvizhenie za Politicheskoe Ravnopravie Zhenshchin v Gody Pervoi Rossiiskoi Revoliutsii", Vestnik Moskovskogo Universiteta, Seriia 8, 2 (1982), p. 35.

(1) Kollontai, Autobiographie einer sexuell emanzipierten Kommunistin, p. 16; Kollontai, Iz Moei Zhizni i Raboty, pp. 89-90; Broido, Wetterleuchten über Rußland, pp. 25-26; Broido, V Riadakh RSDRP, pp. 16-17; E. Preobrazhenskii, "Evgeniia Bogdanovna Bosh", Proletarskaia Revoliutsiia 2 (37), (1925), pp. 6-8; B. Sapir, Iz Arkhiva L.O. Dan, p. $\mathbf{x x}$. 
ground activities and family life. Quite a few female party members had children, yet they were often torn between political obligations and their duties as mothers. Lidiia Tsederbaum recalled how Lenin rebuked her and Inna Smidovich for having left their babies in the care of relatives in order to be free for editorial work with "Iskra". ${ }^{91}$ As far as it is revealed in the handful of memoirs which treat this topic at all, the division of labour in social-democratic marriages followed conventional patterns; in addition to their political tasks, women worked as housewives or hostesses; they alone were responsible for cleaning, cooking and the other chores necessary to turn a hard-working revolutionary into a satisfied husband. Here and there, in the abundance of recollections of Lenin, memoirists shake our faith in this notorious patriarch by depicting him as "Ilich with a dish-cloth", although one may suspect that such stories about the everyday life of the 'old man' attest rather to the flowering of the Lenin cult in the twenties than to trustworthy observations while he was alive. Perhaps Jakov Sverdlov actually was the incarnation of the careful housekeeper and affectionate father which his wife, Novgorodtseva, described him as in her biography. ${ }^{92}$ On the whole, however, traditional rather than subversive attitudes towards private life prevailed among social democrats.

Having analyzed the process of the political radicalization of socialdemocratic women in detail, it is hardly surprising that only a long and winding road could lead them into the RSDRP, and that it necessitated a significant struggle to emancipate themselves from the established notions about the role and the place of women in society. Small wonder then that they tended to keep their own family life intact despite all liberation. It served them perhaps as one of the last residues of stability and beloved custom in their otherwise unsteady lives. They were underground activists, they lived illegally or as emigrants, imprisonment had to be expected at any moment and arrest followed by exile to Siberia were common experiences for most female activists. In this respect at least, the Russian police treated men and women alike. There were basically two motives that made women in the social-democratic movement endure all these hardships: their desire to serve others, and their longing to lead a fuller life themselves as women. The first was certainly cultivated by the spirit of the time, when populist attitudes turned "repentant nobles" into revolutionaries. Moreover, it accorded with what women had been trained for. The other impetus had deeper roots and stemmed from their experience of inferiority as women. Autobiographies of female party members show that most of their worries about injustice were Janus-faced; looked at from a purely political perspective, they appear to be mainly altruistic; yet they were self-centered as well.

${ }^{91}$ Sapir, Iz Arkhiva L.O. Dan, p. xx.

${ }^{22}$ Klawdija Swerdlowa, Jakow Michajlowitsch Swerdlow (Berlin, 1965), p. 218. 
Women social democrats tended to embrace the cause perhaps more for personal reasons than for abstract political ones. Trying to escape the subordination of women in Tsarist Russia played a crucial role in their turning to radicalism.

In this respect women social democrats had much in common with female members of the socialist revolutionary or even the Kadet parties, as well as with feminists and women students. Our analysis of their "making" could therefore be taken as a case-study in female radicalization and emancipation in late Imperial Russia; the reasons behind their political preference for the RSDRP remain vague and do not appear to have been of fundamental importance in their initial politicization.

Later, they were accepted on an equal basis with men in the mixed party-committees as tovarishch Elena, Nadezhda or Ekaterina; yet it soon turned out that they were comrades-in-arms, but not in power. But the success of social-democratic women in Russia should not be measured against that of their male counterparts, but rather it should be compared with the limited range of options which Russian society could offer at the turn of the century. By this standard, they had liberated themselves to a certain degree; but at the same time they had also acknowledged traditional concepts of what was "babe delo". 